\title{
Air-Flotation, Pneumatic Conveying Velocities, and Airflow Relationships for Coffee Fruits and Coffee Beans ${ }^{1}$
}

\author{
Adolfo Eschenwald and Carl W. Hall ${ }^{2}$
}

INTRODUCTION

The world's coffee production and consumption show considerable steady increases $(9)^{3}$. (See table 1). Much research has been done on varieties and cultural practices. Very little basic information is available on the physical properties that could be used for handling and processing. Coffee is a product that requires considerable handling and processing on the farm before it is ready for the market.

The specific objectives of this study were:

1. To determine the air velocities required for flotation and pneumatic conveying of the product.

2. To determine the air-pressure drop per foot depth of the product during different stages of processing.

\section{REVIEW OF LITERATURE}

\section{AIR FLOTATION AND PNEUMATIC CONVEYING}

The Sturtevant Division of Westinghouse Corp. (8) developed air velocities and air-volume conveying curves for general conditions based on the bulk density of the material. The Grain Storage Laboratories, U. S. Department of Agriculture, (10) worked out air velocities required to cause loose grain to move along the bottom of ducts.

Madison (3) published some generally used conveying velocities. The conveying velocity was directly related to the bulk density of the product. $\mathrm{He}$ found that lower velocities were needed to convey material in a vertical pipe than in a horizontal one. In a horizontal pipe low velocities permit a separation of the material from the air stream.

Rice (4) found that particles with dimensions approaching spheres or cubes required the greatest velocity for conveying.

1 Based on Adolfo Eschenwald's Some Basic Properties of the Coffee Fruit and Coffee Beans, a thesis for M.S. degree, Department of Agricultural Engineering, Michigan State University, East Lansing, Mich., 1959.

2 The authors, Adolfo Eschenwald and Carl W. Hall, are, respectively, Agricultural Engineer and Associate Professor in charge of Lajas Substation (formerly graduate student, Michigan State University), and Professor, Agricultural Engineering, Michigan State University, East Lansing, Mich.

Italic numbers in parentheses refer to Literature Cited, p. 331-2. 
TABLE 1.-World green-coffee production and exportable produclion in 1,000 bags' $1954-59$

\begin{tabular}{|c|c|c|c|c|c|c|c|}
\hline \multirow{2}{*}{ Continent } & \multicolumn{5}{|c|}{ Production in- } & \multirow{2}{*}{$\begin{array}{l}\text { Percentage } \\
\text { of total } \\
\text { production } \\
\text { in } 1959\end{array}$} & \multirow{2}{*}{$\mid \begin{array}{c}\text { Percen- } \\
\text { tage in } \\
\text { crease } \\
\text { in pro- } \\
\text { duction } \\
1954 \text { to } \\
1959\end{array}$} \\
\hline & $1954-55$ & $1955-56$ & $1956-57$ & $1957-58$ & 1958-59: & & \\
\hline
\end{tabular}

World green-coffee production

\begin{tabular}{l|r|r|r|r|r|r|r}
\hline North America & \\
South America $^{4}$ & 7,489 & 7,823 & 7,750 & 8,575 & 8,525 & 14.5 & 14 \\
Africa $^{5}$ & 26,022 & 31,575 & 26,040 & 32,780 & 37,980 & 65.0 & 46 \\
Asia and Oceania $^{\circ}$ & 7,112 & 8,749 & 8,775 & 8,600 & 9,560 & 16.3 & 34 \\
& 1,565 & 2,201 & 2,625 & 2,590 & 2,590 & 4.2 & 59 \\
\hline Total world production & 42,188 & 50,348 & 45,190 & 52,545 & 58,655 & & \\
\hline
\end{tabular}

World green-coffee exportable production

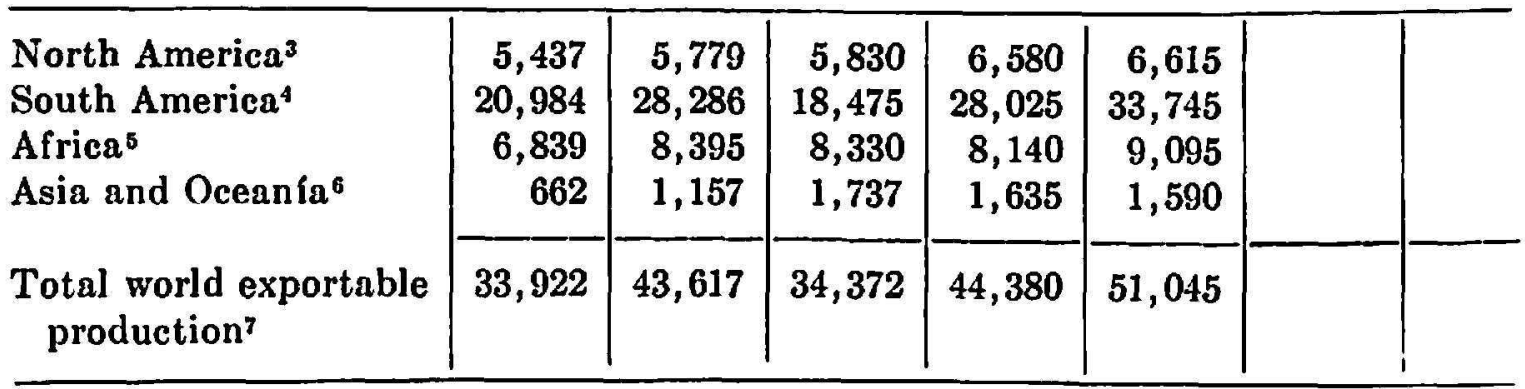

132.276 lb. each.

2 Estimated.

${ }^{3}$ Major producers: Costa Rica, Cuba, Dominican Republic, El Salvador, Guatemala, Haití, Honduras, Mexico, and Nicaragua. Minor producers: Hawaii, Guadalupe, Jamaica, Panama, Puerto Rico, and Trinidad.

4 Major producers: Brazil, Colombia, Ecuador, Peru, and Venezuela. Minor producers: Bolivia, British Guiana, Paraguay, and Surinam.

5 Major producers: Angola, Belgian Congo, Cameroun, Ethiopia, French West Africa, Kenya, Madagascar, Tanganyika, Togo, and Uganda. Minor producers: Cape Verde, Ghana, French Equatorial Africa, Liberia, Nigeria, Sao Tome, Sierra Leone, and Spanish Guinea.

- Major producers: India, Indonesia, and Yeman. Minor producers: New Caledonia, New Hebrides, North Borneo, Philippines, Portuguese Timor, and Vietnam

7 The United States is the major coffee importer with a total of $2,761,190,000$ pounds imported in 1957 , which had a cash value of $1,375,736,000$ dollars. World percentage exportable production was 87 .

\section{AIRFLOW RELATIONSHIPS}

Henderson (2) determined and evaluated the airflow relationships for shelled corn. Information was needed for the design of natural and mechanical ventilating and drying systems. The results of the tests were mathe- 
matically expressed and the basic formula for clean shelled corn was developed as follows:

$$
Q=K P^{c}
$$

where

$Q=$ cubic feet per minute (c.f.m.) of air per square foot

$K=$ function of depth of grain

$c=$ slope of the curve

$P=$ pressure drop in inches of water

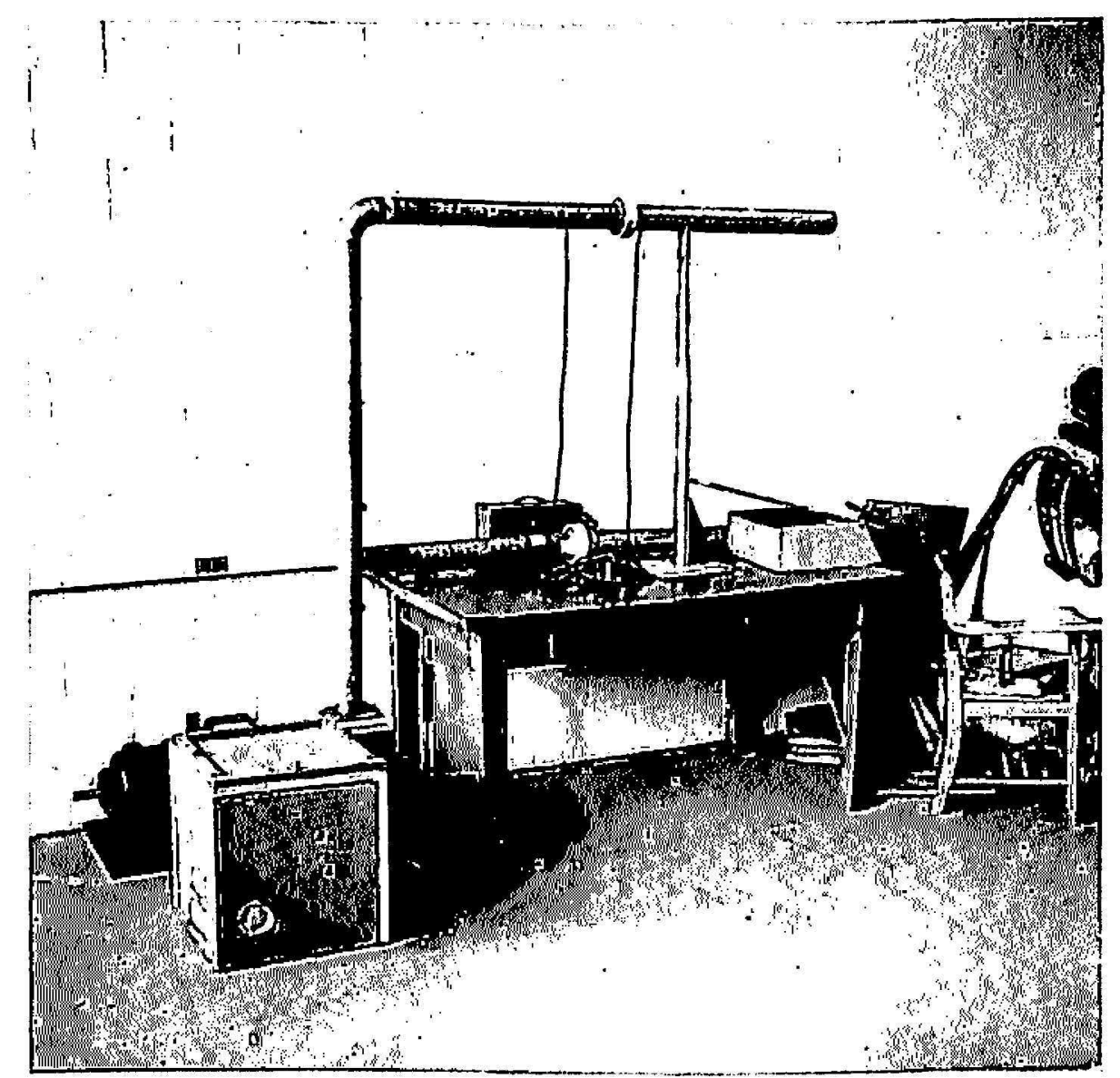

Fig. 1.-Equipment used for airflow-relationship studies.

Shedd (5) conducted some experiments on the resistance of ear corn to airflow. Airflow rates of 10, 20,30, 40, 50, 60, and 70 c.f.m. per square foot were used. A pitot-tube installation was used to measure the airflow. Data plotted on logarithmic scale with airflow, $Q$, versus static pressure, $P$, resulted in a straight line.

Shedd $(6,7)$ reported data on the resistance of grain to airflow. He found that the general slope of the curve is greater for fine than for coarse material. If the material is fine the above-mentioned formula will fit the curve for only a narrow range of airflow rates. 


\section{PROCEDURE}

AIR FLOTATION AND PNEUMATIC CONVEYING

The air-flotation velocities were determined for the green and ripe fruits, fresh pulp, and pulped washed wet coffee beans. A pitot-tube installation

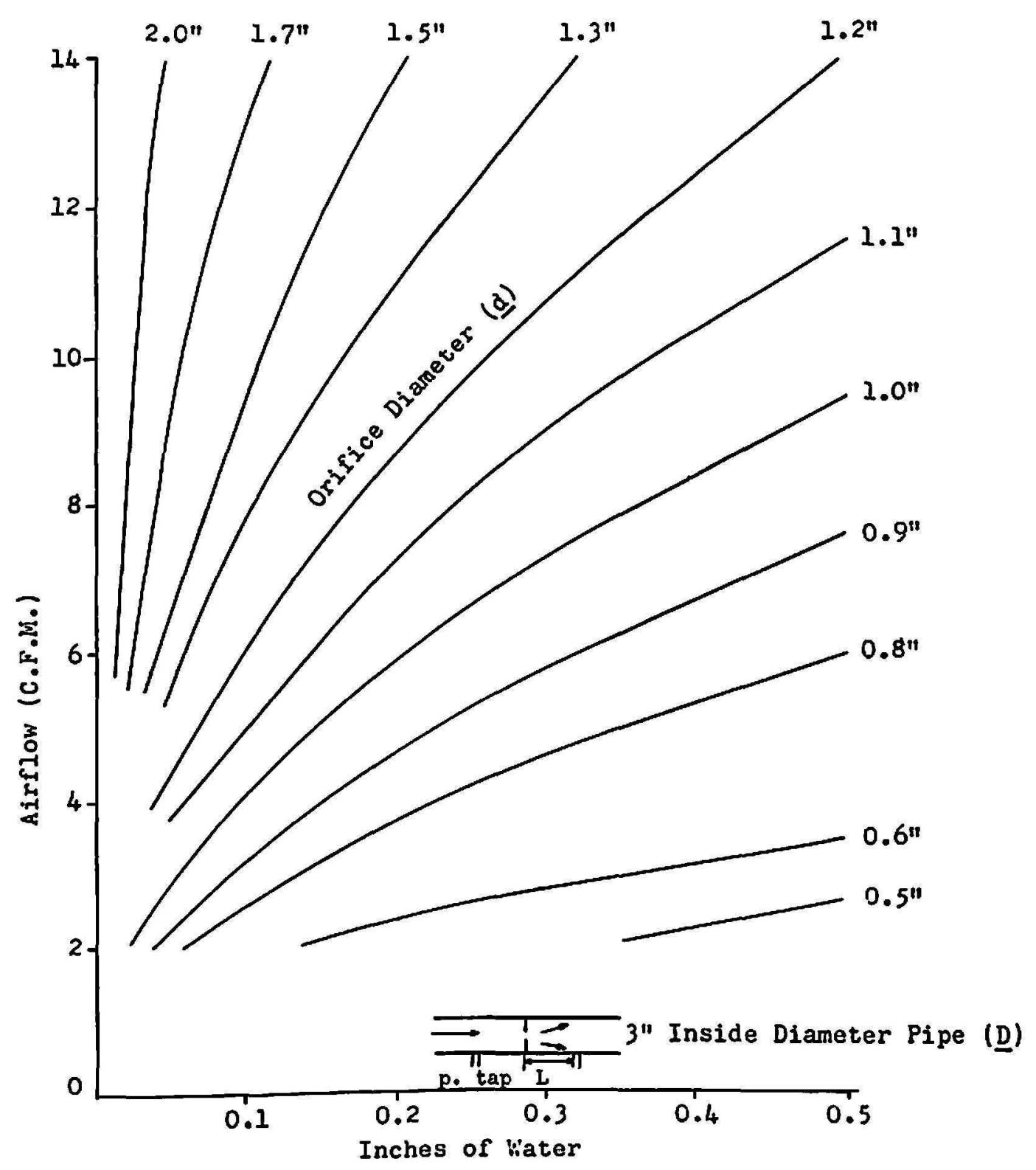

Fig. 2.-Pressure drop through orifice (inches of water):

$$
L=0.90 D\left[1-(d / D)^{2}\right] Q=4,005 C A \sqrt{p}
$$

was used to measure the air velocity. The pressure difference $\left(P_{2}-P_{1}\right)$ between the static pressure tap and the impact pressure tap was measured with an inclined tube manometer (type-C micromanometer). The air was supplied by a type $P$, electrically powered $1 / 4$ hp., 3,400-r.p.m. fan, manu- 
factured by the Electric Ventilating Co. The air velocity for flotation was determined for 50 samples in each case, taking the average of 5 readings. Flotation velocities were calculated in feet per minute (f.p.m.), using the

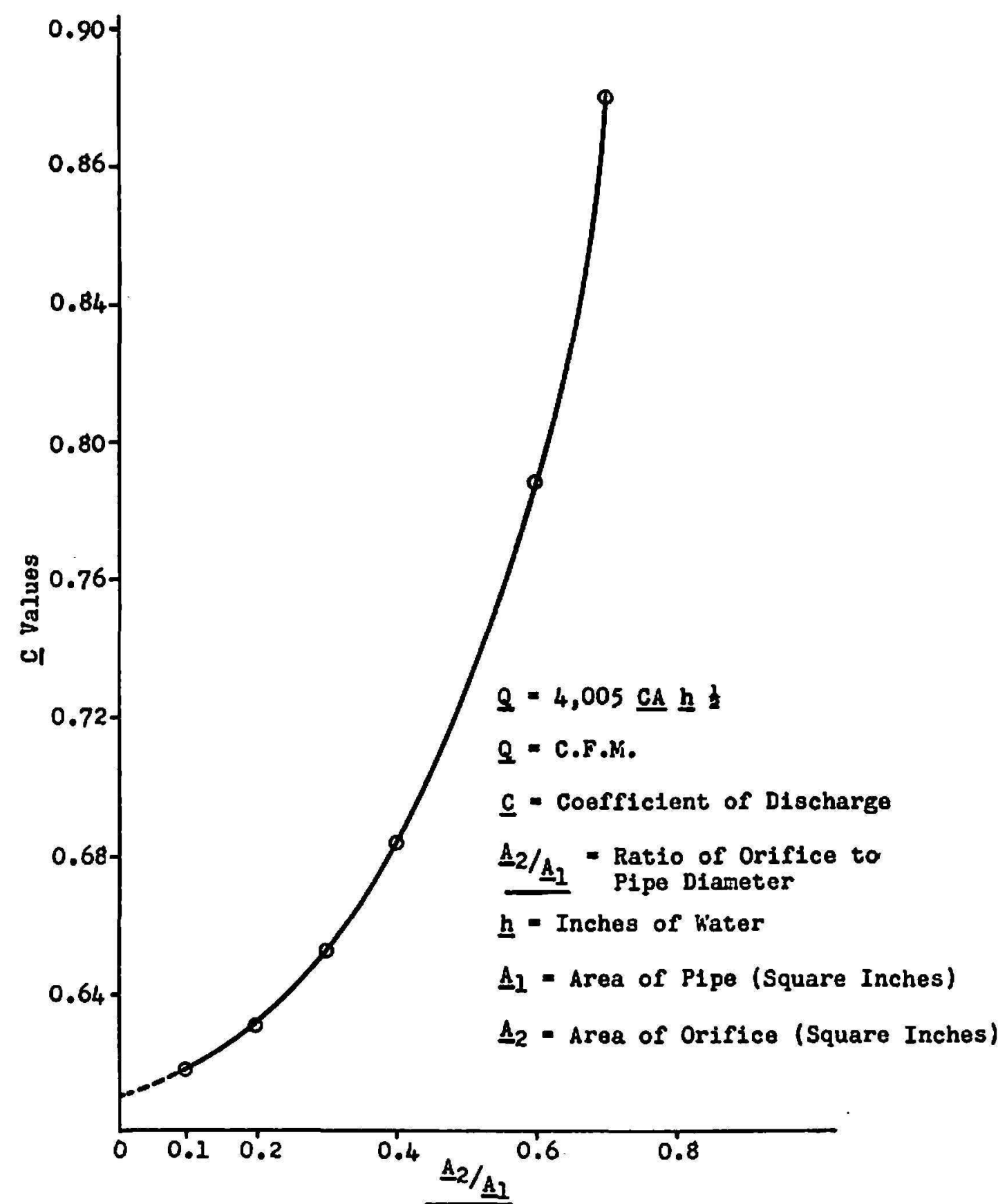

Fug. 3.-Coefficient of discharge $C$ for an 0.5 -inch vena-contracta orifice in a 3 -inch pipe. (From Fan Engineering Handbook (s)).

pitot-tube formula (Eckman, 1) adjusted for the room air conditions. The conveying air velocity was figured by adding 30 feet per second, (f.p.s.) or 1,800 f.p.m. to the flotation velocity. 
TABLE 2.-Average air velocities for conveying coffee fruits, pulp, and beans

\begin{tabular}{|c|c|c|c|c|c|}
\hline Material & $\begin{array}{l}\text { Pressure of } \\
\text { water }\end{array}$ & $\begin{array}{l}\text { Flotation } \\
\text { velocity }\end{array}$ & $\begin{array}{l}\text { Conveying } \\
\text { velocity? }\end{array}$ & $\underset{\text { densityz }}{\text { Bulk }}$ & $\begin{array}{l}\text { Sturtevant } \\
\text { conveying } \\
\text { velocities' }\end{array}$ \\
\hline & In. & Ft./min. & Ft./min. & Fl./min. & Fl. $/$ min. \\
\hline Green fruits & 0.881 & 3,883 & 5,683 & 37.54 & 5,600 \\
\hline Ripe fruits & .910 & 3,950 & 5,750 & 37.24 & 5,550 \\
\hline Fresh pulp & .572 & 3,125 & 4,925 & 15.48 & 4,100 \\
\hline Pulped washed beans & .786 & 3,655 & 5,455 & & \\
\hline
\end{tabular}

${ }^{1}$ Calculated by formula $4,140 \sqrt{h^{\prime}}$.

2 Flotation velocity $+1,800$ f.p.m.

${ }^{3}$ From specific gravity determinations.

4 From Sturtevant conveying curve.

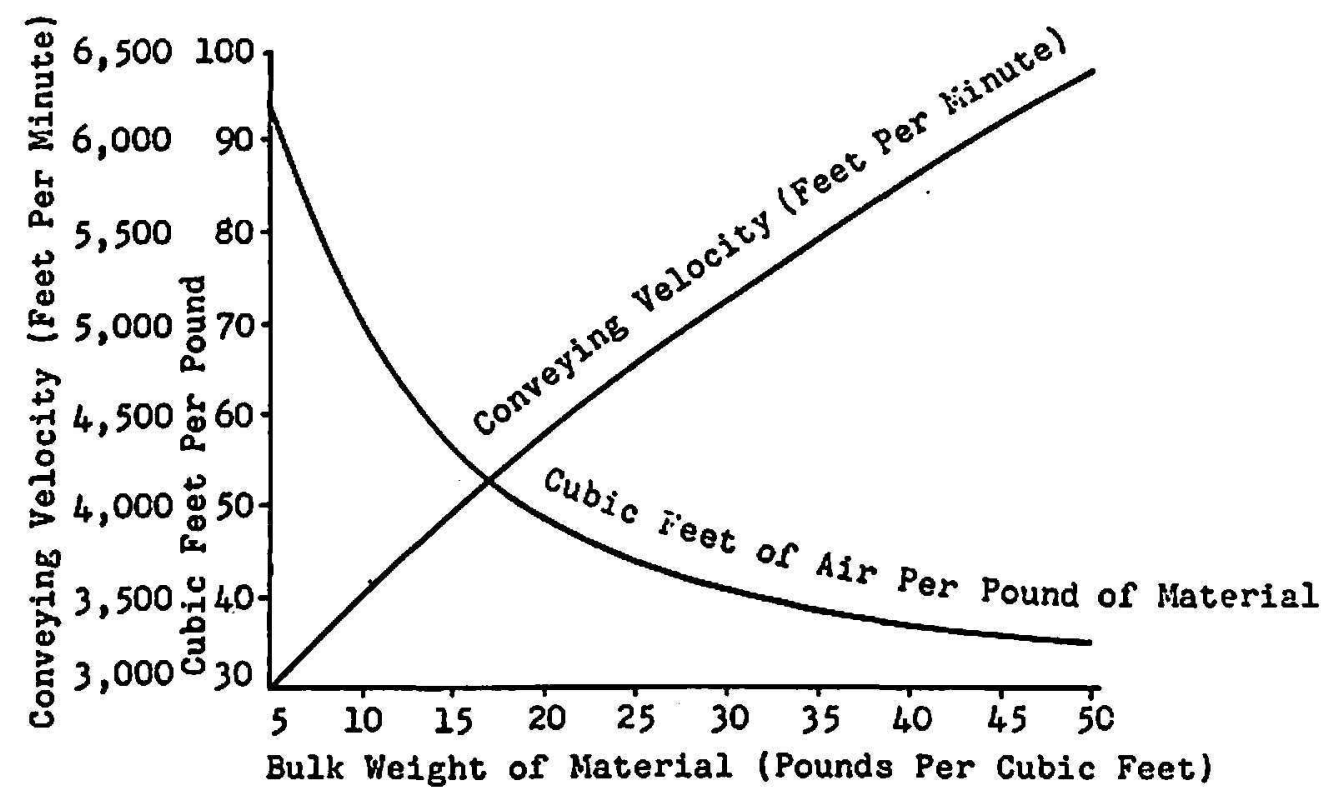

Fig. 4.-Average velocities and air volumes for conveying material. Reproduced by permission of the Sturtevant Division, Westinghouse Corp.

The basic equation for a pitot-tube fluid velocity measurement is as follows:

$$
V=C_{p t} \sqrt{\left(d_{m}-d_{f}\right) v} \sqrt{2 g h}
$$

$V=$ Velocity of flowing fluid in feet per second

$C_{p t}=$ Velocity coefficient, a constant, aproximately 1

$d_{m}=$ Density of manometer fluid in pounds per cubic foot

$d_{f}=$ Density of fluid over the manometer fluid in pounds per cubic foot

$v \quad=$ Specific volume of the flowing gas in cubic feet per pound 
$g \quad=$ Acceleration due to gravity in feet per second per second

$h=$ Manometer differential in feet

Since $C_{p \iota}=$ Approximately $1 \quad d_{m}=62.4$

Then

$$
d_{f}=0 \quad g=32.2
$$

$$
V=\sqrt{(62.4)(64.4) v h}
$$

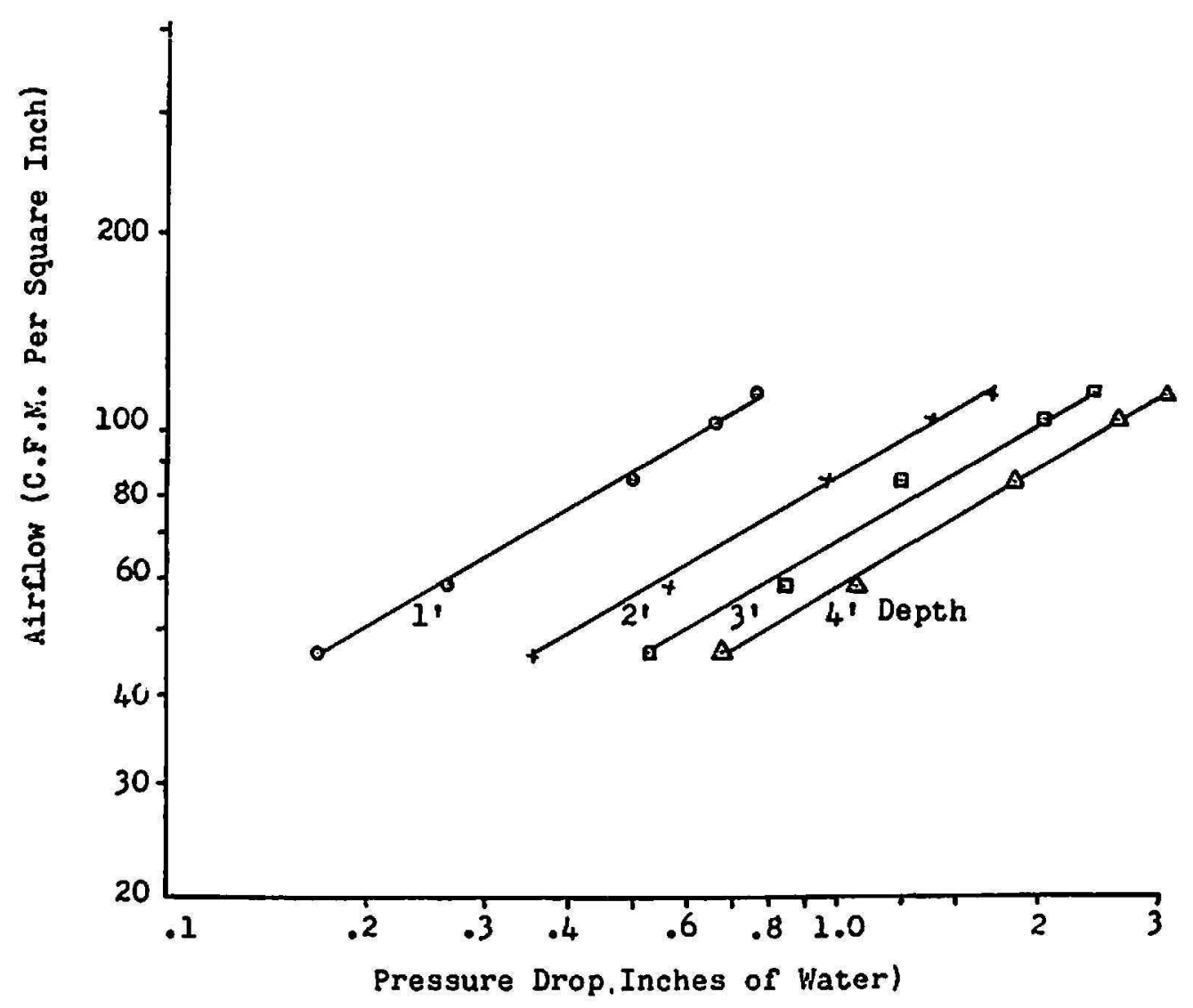

Fic. 5.-Resistance of ripe coffee fruit to airflow.

As the manometer differential is measured in inches of water, let

$$
V=\sqrt{\frac{h=h^{\prime} / 12}{12}}=\sqrt{334.2 v h^{\prime}}
$$

Using $v=14.5$

$$
\begin{aligned}
V & =\sqrt{(334.2)(14.5) h^{\prime}} \\
V & =69 \sqrt{h^{\prime}} \text { in f.p.s. } \\
v & =4,140 \sqrt{h^{\prime}} \text { in f.p.m. }
\end{aligned}
$$




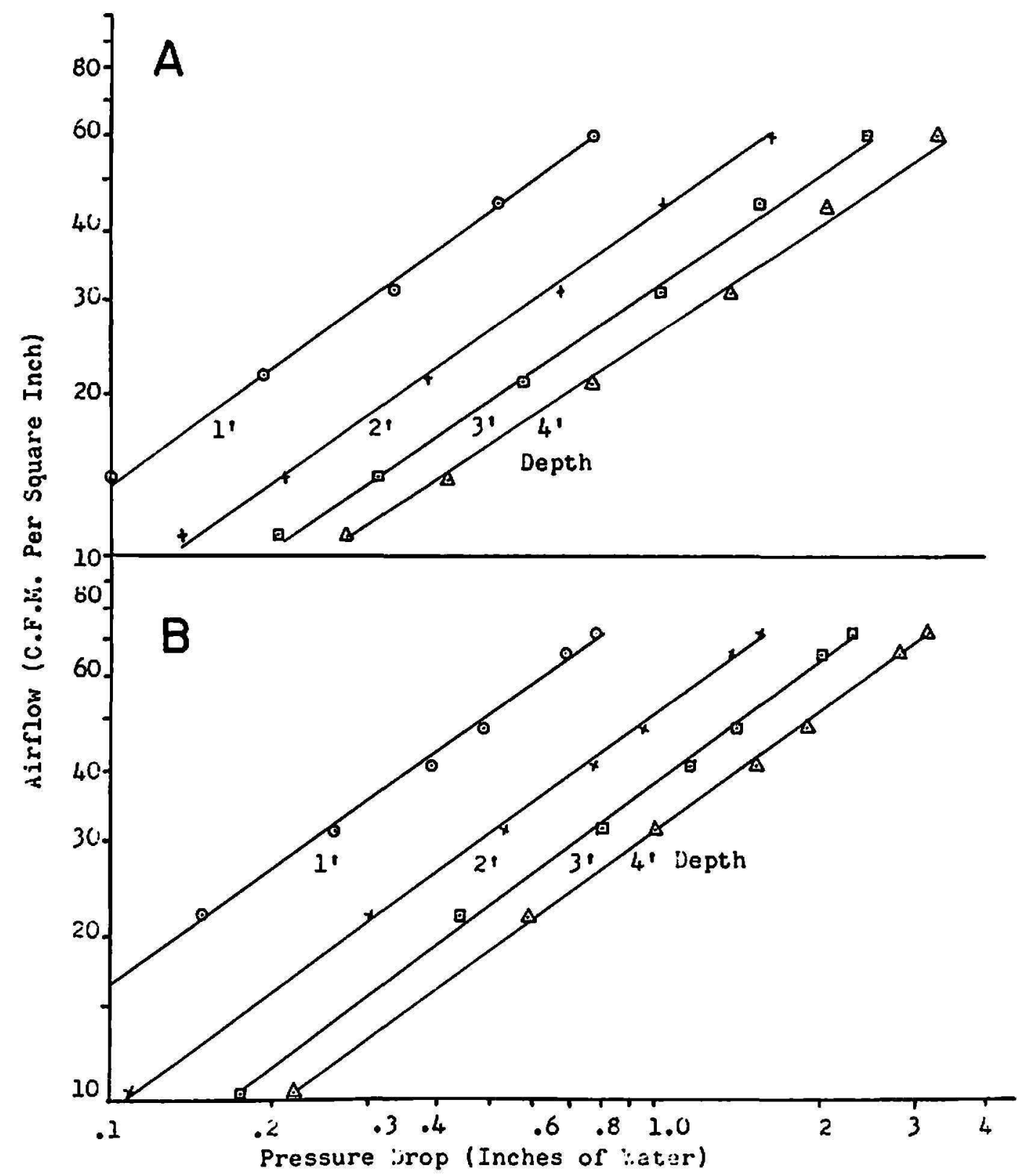

FIG. 6.-Resistance of parchment coffee at percentage moisture contents indicated to airflow: A, Washed wet coffee beans; percentage moisture, wet basis, 55.6 at beginning and 53.5 at end of test. B, Washed coffee beans; percentage moisture, wet basis, 52.0 at beginning and 49.1 at end of test. $C$, Washed coffee beans; percentage moisture, wet basis, 45.4 at beginning and 45.0 at end of test. D, Dried coffee beans; percentage moisture, wet hasis, 13.3 at beginning and 11.7 at end of test. See p. 327 for remainder of fig. 6 .

The generally accepted pneumatic conveying velocity is the flotation air velocity plus from 30 to 50 f.p.s. Taking the experimental value obtained for ripe coffee as an example and applying the simplified pitot-tube formula the result is as follows:

$$
\begin{aligned}
& 4,140 \sqrt{h^{\prime}}=4,140 \sqrt{0.910} \\
= & 3,9 ; 0 \text { flotation velocity in f.p.m. }
\end{aligned}
$$


The conveying velocity then is equal to the flotation velocity $(3,950$ f.p.m.) plus 1,800 f.p.m. added for conveying as explained above.

\section{AIRFLOW RELATIONSHIP}

The resistance of coffee to airflow was determined for green fruits, ripe fruits, washed wet parchment-coffee beans (55.6- to 53.5-percent moisture,

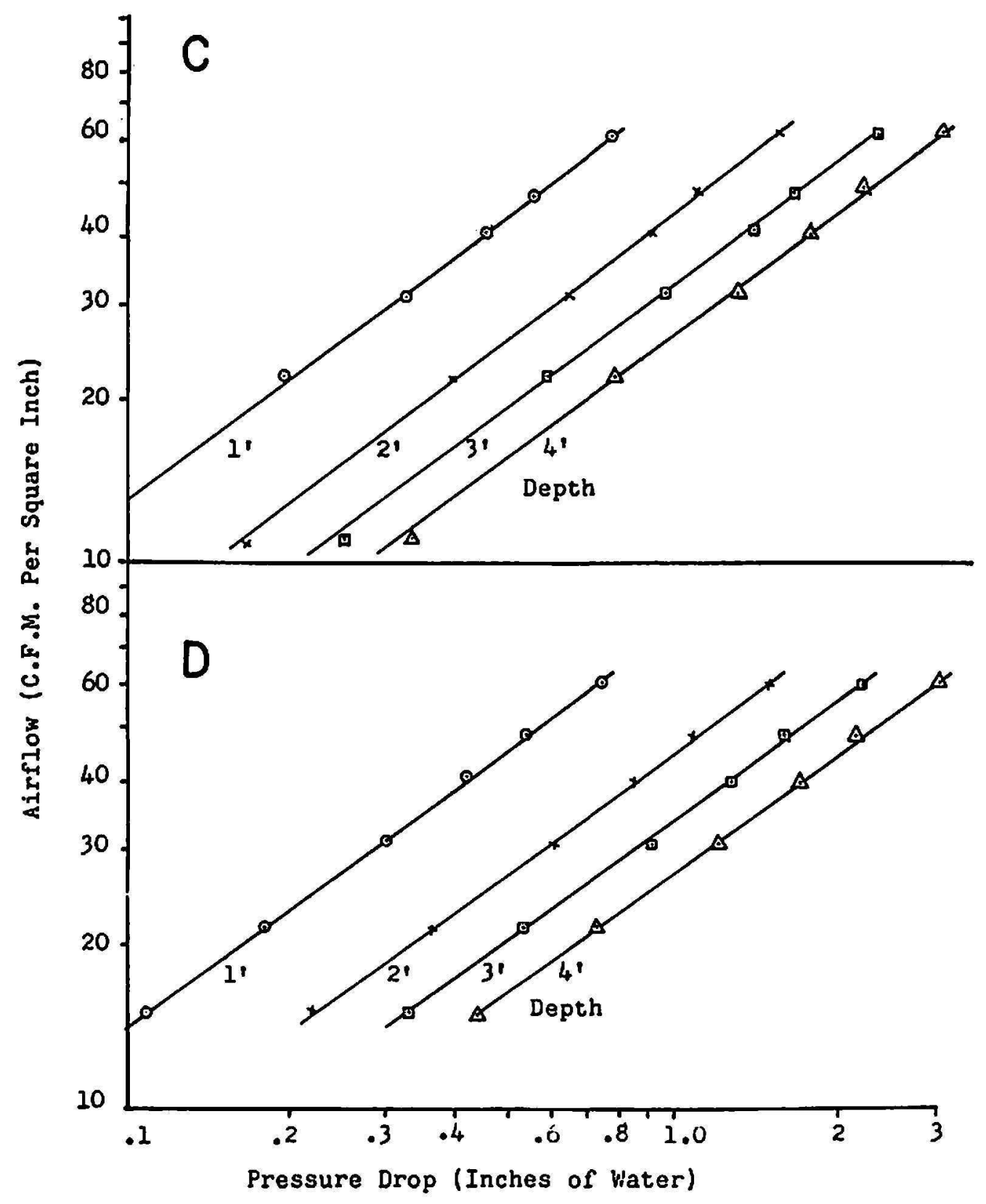

Fra. 6.-C and D

wet basis); partly dried parchment coffee (52.0- to 49.1-percent moisture, wet basis and 45.4- to 45.0-percent moisture, wet basis); and dried parchment coffee (13.3- to 11.7-percent moisture content, wet basis.)

A centrifugal radial-flow, electrically powered fan was used to supply 
the air. The outlet of the fan was connected to an airtight plywood box which provided a uniform steady flow. Sliding gates at the inlet and outlet of the box regulated the desired flow. From this box the air passed into a

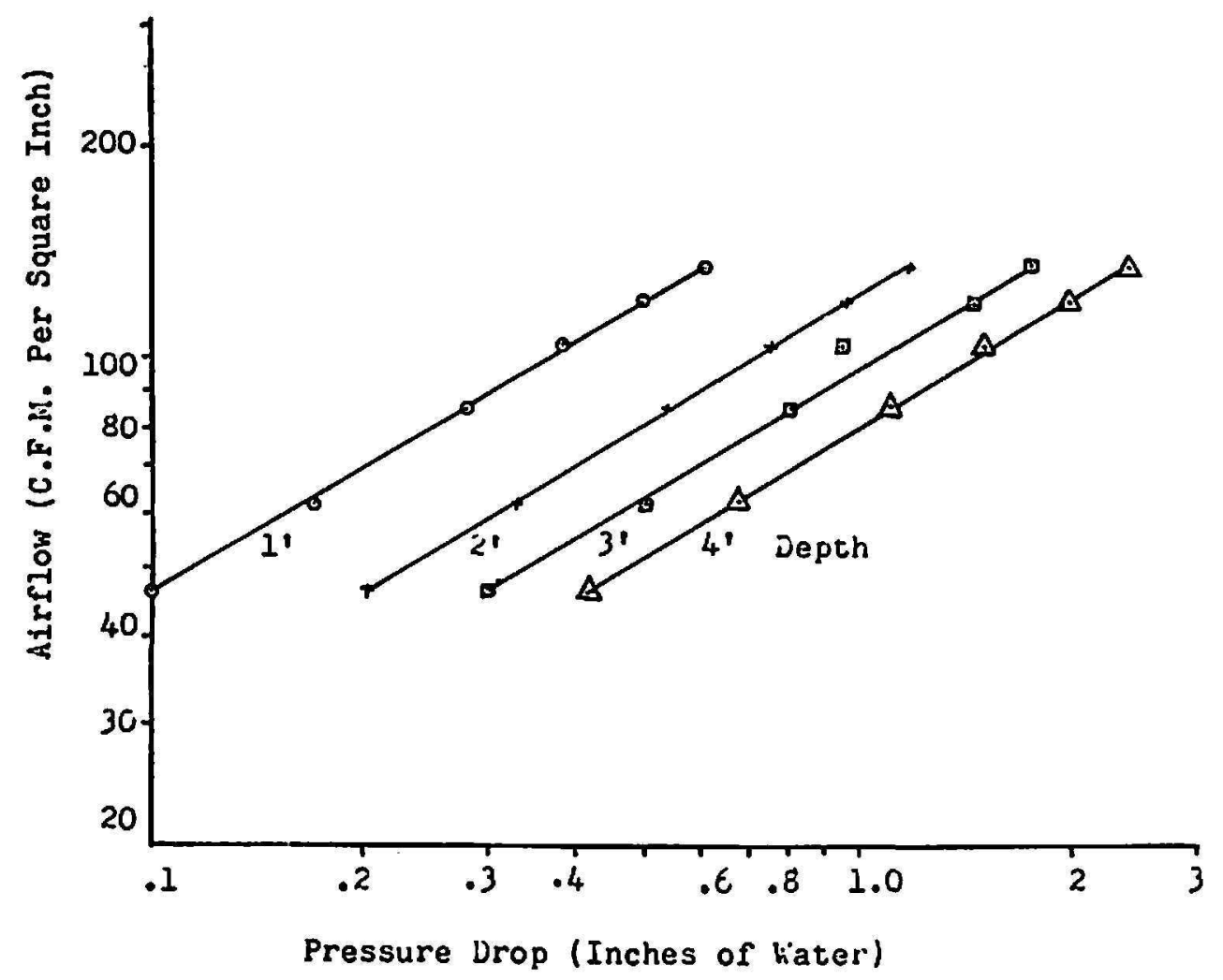

Fra. 7.-Resistance of green coffee fruit to airflow.

Table 3.-Resistance of ripe coffee fruits to airflow

\begin{tabular}{c|c|c|c|c}
\hline \multirow{2}{*}{$\begin{array}{c}\text { Airflow } \\
\text { (c.f.m./sq. ft.) }\end{array}$} & \multicolumn{3}{|c}{ Pressure drop at indicated inches of water } \\
\cline { 2 - 5 } & 1 ft. & 2 ft. & 3 ft. & 4 ft. \\
\hline 46 & 0.170 & 0.354 & 0.530 & 0.680 \\
58 & .264 & .562 & .842 & 1.075 \\
84 & .496 & .970 & 1.250 & 1.850 \\
103 & .657 & 1.378 & 2.067 & 2.630 \\
112 & .761 & 1.590 & 2.385 & 3.043 \\
\hline
\end{tabular}

smaller box that served as the base for the coffee holding tower. The tower consisted of a 3-inch inside-diameter pipe 5 feet long. A screen was soldered to the lower end to hold the product and taps were provided at 1-foot intervals. A vena-contracta, orifice-type meter was used to measure the airflow (fig. 1). Airflow rates varying from 10 to 70 c.f.m. per square foot were 
TABLE 4.-Resistance of washed wet parchment coffee beans to airflow ${ }^{1}$

\begin{tabular}{c|r|r|r|r}
\hline \multirow{2}{*}{$\begin{array}{c}\text { Airfow } \\
\text { (c.f.m./sq. ft.) }\end{array}$} & \multicolumn{3}{|c}{ Pressure drop at indicated inches of water } \\
\cline { 2 - 5 } & $1 \mathrm{ft}$. & $2 \mathrm{ft}$. & \multicolumn{1}{c}{$3 \mathrm{ft.}$} & $4 \mathrm{ft}$. \\
\hline 11.0 & 0.067 & 0.136 & 0.204 & 0.268 \\
14.0 & .105 & .208 & .312 & .418 \\
20.0 & .188 & .378 & .567 & .754 \\
30.0 & .335 & .677 & 1.015 & 1.340 \\
45.0 & .508 & 1.014 & 1.521 & 2.032 \\
60.0 & .760 & 1.607 & 2.411 & 3.240 \\
\hline
\end{tabular}

1 Immediately after washing: Percentage moisture, wet basis, at beginning of test 55.6, and at end of test 53.5.

TABLE 5.-Resistance of washed parchment coffee beans to airflow at 52-10 49.1-percent moisture, wet basis ${ }^{1}$

\begin{tabular}{c|c|c|c|c}
\hline \multirow{2}{*}{$\begin{array}{c}\text { Airflow } \\
\text { (c.f.m./sq. ft.) }\end{array}$} & \multicolumn{3}{|c}{ Pressure drop at indicated inches of water } \\
\cline { 2 - 3 } & 1 ft. & 2 ft. & 3 ft. & 4 ft. \\
\hline 11.0 & 0.058 & 0.107 & 0.175 & 0.220 \\
21.7 & .146 & .293 & .440 & .585 \\
31.3 & .259 & .532 & .796 & 1.025 \\
40.7 & .386 & .765 & 1.147 & 1.535 \\
48.0 & .467 & .943 & 1.415 & 1.870 \\
67.5 & .683 & 1.354 & 2.081 & 2.733 \\
72.0 & .770 & 1.537 & 2.305 & 3.080 \\
\hline
\end{tabular}

${ }^{1}$ Air-dried for 6 hours: Percentage moisture, wet basis, at beginning of test 52.0 , and at end of test 49.1 .

TABLE 6.-Resistance of washed parchment coffee beans to airflow at 45.4-percent moisture, wet basis ${ }^{1}$

\begin{tabular}{c|r|r|r|r}
\hline \multirow{2}{*}{$\begin{array}{c}\text { Airflow } \\
\text { (c.f.m./sq. ft.) }\end{array}$} & \multicolumn{4}{|c}{ Pressure drop at indicated inches of water } \\
\cline { 2 - 5 } & 1 ft. & 2 ft. & 3 ft. & 4 ft. \\
\hline 11.0 & 0.086 & 0.165 & 0.250 & 0.335 \\
21.7 & .196 & .393 & .590 & .785 \\
31.3 & .326 & .643 & .965 & 1.305 \\
40.7 & .456 & .910 & 1.435 & 1.825 \\
48.8 & .556 & 1.102 & 1.653 & 2.225 \\
60.6 & .782 & 1.560 & 2.340 & 3.130 \\
\hline
\end{tabular}

${ }^{1}$ Air-dried for 24 hours: Percentage moisture, wet basis, at beginning of test 45.4 and at end of test 45.0 . 
used. The airflow rates were calculated from airflow pressure-drop curves and also from data provided by Fan Engineering Handbook. (See figs. 2 and 3).

\section{RESULTS AND DISCUSSION}

The data obtained for flotation and conveying velocities are presented in table 2. The values calculated with the formula applied to the results ob-

TABLE 7.-Resistance of dried parchment coffee beans to airflow ${ }^{1}$

\begin{tabular}{l|r|r|c|c}
\hline \multirow{2}{*}{$\begin{array}{c}\text { Airfiow } \\
\text { (c.f.m./sq. ft.) }\end{array}$} & \multicolumn{3}{|c}{ Pressure drop at indicated inches of water } \\
\cline { 2 - 4 } & 1 ft. & $2 \mathrm{ft}$. & $3 \mathrm{ft.}$ & $4 \mathrm{ft.}$ \\
\hline 15 & 0.111 & 0.220 & 0.330 & 0.443 \\
21.7 & .180 & .363 & .534 & .730 \\
31.3 & .305 & .607 & .910 & 1.220 \\
40.7 & .420 & .837 & 1.255 & 1.680 \\
48.8 & .536 & 1.082 & 1.622 & 2.145 \\
60.6 & .741 & 1.476 & 2.214 & 2.965 \\
\hline
\end{tabular}

${ }_{1}^{1}$ Air-dried for 10 days: Percentage moisture, wet basis, at beginning of test 13.3, and at end of test 11.7.

TABLE 8.-Resistance of green coffee fruits to airflow

\begin{tabular}{c|c|c|c|c}
\hline \multirow{2}{*}{$\begin{array}{c}\text { Airfow } \\
\text { (c.f.m./sq. ft.) }\end{array}$} & \multicolumn{3}{|c}{ Pressure drop at indicated inches of water } \\
\cline { 2 - 5 } & $1 \mathrm{ft.}$ & $2 \mathrm{ft}$. & $\mathrm{3} \mathrm{ft.}$ & $4 \mathrm{ft}$. \\
\hline 46 & 0.102 & 0.204 & 0.306 & 0.418 \\
62 & .170 & .332 & .497 & .680 \\
84 & .276 & .536 & .804 & 1.104 \\
103 & .382 & .746 & .940 & 1.530 \\
118 & .495 & .962 & 1.442 & 1.980 \\
133 & .601 & 1.168 & 1.752 & 2.405 \\
\hline
\end{tabular}

tained in the tests are very close to the values obtained by using the Sturtevant air conveying curve developed by Westinghouse Corp. (8) (fig. 4).

Tables 3 to 8 and figures 5 to 7 show the results obtained for the resistance of coffee fruits and coffee beans to airflow. Ripe coffee fruits offer a higher resistance to airflow than the green fruits. This must be taken into consideration in ventilating or cooling a batch of mixed or partly ripe fruits. In the washed parchment beans the higher the moisture content, the higher the resistance to airflow. Driers must be designed on the maximum resistance to take care of the initial drying period. 


\section{SUMMARY}

Air-flotation and -conveying velocities for coffee fruits, pulp, and beans determined and calculated using the pitot-tube formula, under normal air conditions, compare favorably with values in work done with other crops and fit closely in the Sturtevant pneumatic conveying curve developed by Westinghouse (8). Air-conveying velocities of $5,683,5,750,4,925$, and 5,455 feet per minute were obtained for green fruits, ripe fruits, pulp, and pulped washed beans, respectively. Ripe coffee fruits offer a higher resistance to airflow than the green ones. The higher the moisture content in parchment coffee the higher the resistance to airflow. A straight-line relationship results when the static pressure, in inches of water, is plotted logarithmically versus the airflow for coffee fruits and beans.

\section{RESUMEN}

Las velocidades necesarias para la flotación y el transporte por corriente de aire de las cerezas, la pulpa, y granos del café, determinadas y calculadas según la fórmula del tubo de Pitot bajo condiciones normales de aire, comparan favorablemente con los resultados obtenidos para otros productos y se ajustan estrechamente a la curva de Sturtevant desarrollada por Westinghouse (8). Las velocidades que se obtuvieron para las cerezas verdes, las cerezas maduras, la pulpa y el café despulpado y lavado fueron de 5,683 , $5,750,4,925$, y 5,455 pies por minuto, respectivamente.

Las cerezas maduras of recen una mayor resistencia al flujo de aire que las cerezas verdes. En el caso del café pergamino, a mayor contenido de humedad, mayor es la resistencia al flujo de aire. Al trazar en una gráfica logarítmica los valores de presión estática en pulgadas de agua contra los valores correspondientes de velocidades de aire, se obtiene una relación rectilínea tanto en el caso de las cerezas como en el café pergamino.

\section{LITERATURE CITED}

1. Eckman, D. P., Industrial Instrumentation, Wiley and Sons, Inc., New York, N. Y., 396 pp., 1957.

2. Henderson, S. M., Resistance of shelled corn and bin walls to airflow, Agr. Engr. 24 367-96, 1943.

3. Madison, R., Editor, Fan Engineering, Buffalo Forge Co., Buffalo, N. Y., 808 pp., 1949.

4. Rice, C. E., The Effect of Particle Size, Shape, and Density on Minimum Pneumatic Suspension and Vertical Transport Velocities; rough draft of thesis for Ph.D., Department of Agricultural Engineering, Mich. State Univ., East Lansing, Mich., 1958.

5. Shedd, C. K., Resistance of ear corn to airflow, Agr. Engr. 26 19-20, 1945.

6. - - Some new data on resistance of grain to airflow, Agr. Engr., 32 439-95, and $520,1951$. 
332 JOURNAL OF AGRICULTURE OF UNIVERSITY OF PUERTO RICO

7. - - Resistance of grain and seed to airflow, Agr. Engr. 34 116-69, 1953.

8. Average Velocities and Air Volume for Conveying Material, Sturtevant Division, Westinghouse Corp., 1946.

9. USDA World Summaries of Foreign Crops and Markets, Foreign Agricultural Service, Washington 25, D. C., 1958.

10. USDA Data from Tests made in USDA Grain Storage Laboratory, Ames, Iowa, n.d. 